ISSN(print): 2644-0490, ISSN(online): 2644-0504

Volume 4 Issue 05 May 2021

Article DOI: 10.47191/iefms/v4-i5-30 , Impact Factor: 6.228

Page No.- 633-640

\title{
Production Management and Feasibility of Patin (Pangasius Sp.) Cultivation in Banjar Regency, South Kalimantan Province, Indonesia
}

\author{
Rina Mustika ${ }^{1}$, Emmy Sri Mahreda ${ }^{2}$, Ferni Kurniawaty ${ }^{3}$, Yusrin Rizqiady ${ }^{4}$, Widya Kartika ${ }^{5}$ \\ ${ }^{1}$ Fisheries Socio-Economic Studi Program, Lambung Mangkurat University, ORCHID id 0000-0002-5130-6726 \\ ${ }^{2}$ Fisheries Socio-Economic Studi Program, Lambung Mangkurat University, Professor \\ 3,4,5 Fisheries Socio-Economic Studi Program, Lambung Mangkurat University, Thesis level Student
}

\begin{abstract}
This study aims to analyze production management and to analyze the financial feasibility of patin fish cultivators in Banjar Regency as one of the production centers for patin cultivation in South Kalimantan Province, whether the business has been well managed and the results can make the cultivators prosperous. The results showed that the production management carried out in the patin fish culture business in Banjar Regency consists of pre-production management, production management and post-production management and most of the Good Fish Cultivation Practices according to the Decree of the Minister of Marine Affairs and Fisheries Number 02 / MEN / 2007 has run on the production management of this business. The patin fish farming business in Banjar Regency is financially profitable and feasible to develop.
\end{abstract}

KEYWORDS: Patin, production management, feasibility, Return Cost Ratio, Payback Period, Break Even Point

\section{INTRODUCTION}

Banjar Regency is located in the southern part of South Kalimantan Province, at $114^{\circ} 30$ '20 "and $115^{\circ} 33^{\prime} 37^{\prime \prime}$ East Longitude and $2^{\circ} 49$ '55 "and $3^{\circ} 43^{\prime} 38$ South Latitude. Its area is $4,668.50 \mathrm{Km}^{2}$ or around $12.20 \%$ of the total area of South Kalimantan Province Banjar Regency is one of the 5 regencies / cities in South Kalimantan Province which has the potential for public waters and marine waters. Until now, the fisheries sector is one of the leading sectors in Banjar Regency, South Kalimantan, which contributes to Gross Regional Domestic Product (GRDB)of around five percent, and by 2021, the fisheries sector is expected to be able to contribute six percent to the GRDB of Banjar Regency (Dinas Perikanan Kabupaten Banjar, 2016). The potential of marine and public waters resources has been utilized by the community for fishing and cultivation activities. .

The fishing activities carried out by the community include fishing activities in marine waters and public waters (reservoirs, rivers and swamps), the types of fish produced are sea patin (catfish), snapper, gulamah, pestle, mullet, krosok shrimp, white shrimp, dogol shrimp for catches in the sea with a total production of 5,846 tons in 2019. The types of fish caught in public waters are snakehead fish, betok, toman, sepat siam, tilapia, nilem, patin (catfish), betutu, jambal, sepat rawa, baung, hampala, carp , giant prawns and other types of shrimp with a total production of 2,818 tonnes in 2019 (BPS Kabupaten Banjar, 2020). Meanwhile, fishery cultivation activities carried out by the community include fish rearing (including hatchery) fish in soil and concrete pools, tarpaulin pools, floating net ponds, and cages in the Riam Kanan watershed. In addition, there is also fish rearing using the Minapadi system or fish rearing systems and methods in rice fields in several sub-districts.

Banjar Regency has also become one of the pilot Minapolitan areas for patin (catfish) commodities. Patin is the largest commodity compared to other types of fish produced from cultivation by the community in Banjar Regency. Production data of Patin and other types of fish from aquaculture can be seen in Table 1.

Table 1. Data on cultivated fish production by type in Banjar Regency in 2017 - 2019.

\begin{tabular}{|l|l|l|l|}
\hline Fish & $\mathbf{2 0 1 7}$ & $\mathbf{2 0 1 8}$ & $\mathbf{2 0 1 9}$ \\
\hline Nila & 14649,69 & 14598,78 & 14290,37 \\
\hline
\end{tabular}


Production Management and Feasibility of Patin (Pangasius Sp.) Cultivation in Banjar Regency, South Kalimantan Province, Indonesia

\begin{tabular}{|l|l|l|l|}
\hline Patin & 30187,75 & 37795,48 & 39874,89 \\
\hline Lele & 5177,08 & 3397,44 & 3567,31 \\
\hline Mas & 1971,21 & 1338,86 & 1354,65 \\
\hline Bawal/other & 6119,27 & 3739,79 & 3926,78 \\
\hline Jumlah & $\mathbf{5 8 1 0 5 , 0 0}$ & $\mathbf{6 0 8 7 0 , 3 6}$ & $\mathbf{5 8 ~ 0 1 5 , 4 9}$ \\
\hline
\end{tabular}

Source: Badan Pusat Statistik Kabupaten Banjar, 2020

Aquaculture is defined as an activity to produce aquatic biota (organism) in a controlled manner in order to gain profit. In addition, aquaculture can play a role as human intervention or efforts to increase aquatic productivity through cultivation activities. The cultivation activity referred to is the maintenance effort to maintain survival, grow and reproduce aquatic biota (Efendi, 2004). Aquaculture can be classified into various types of locations according to adequate water conditions for the fish farming process, including freshwater cultivation, brackish water cultivation and sea water cultivation. In freshwater fish farming, there are several types of containers that can be used, including ponds, tubs, aquariums, floating nets / floating net cages. The types of ponds can be distinguished based on the cultivation system to be applied and the water source used (Youdastyo, 2010).

Cultivation with containers and the construction of calm water ponds is commonly practiced by the community, both fish cultivators and the general public. The characteristic of this calm water pond is that the water flow is relatively constant or there is little water replacement. The pond is usually made of soil, it can also be combined with the provision of stones and cement, or with modification of the pond using a tarpaulin. This aquaculture container is used for the cultivation of consumption fish such as patin, tilapia, lele or gouramy. (Rezeki et al, 2019). Fish farming technology using ponds is an artificial water that is wide, limited and deliberately made to be easy to manage in terms of water regulation, types of cultivated animals and target functions. Besides being a living medium for fish, it can also function as a natural food source for fish, meaning that the pond has the potential to grow natural food. Besides that, fish farming in ground ponds has several advantages, including: more practical and easier to make, small capital investment and easy to do drying, harvesting, with an intlet and outlet water gate system (Suraya, 2016).

Patin is a fish that is increasingly in demand in Indonesia and is one of the mainstays in increasing aquaculture productivity. This can be proven by the increase in patin fish production in 2015 amounting to 339,069 tonnes and increasing to 437.11 tonnes in 2016, the production of patin fish continues to increase, where the national target for patin fish production in 2019 is 1,149,400 tonnes (KKP 2016). Increased fish production can be achieved through the aquaculture process because increased production through fishing can interfere with the sustainability of fishery resources (Andrianto, et al. 2012).

Puspita and Wiryono (2014) state that one of the leading fisheries businesses in Indonesia is patin fish. Patin fish is an important fish in aquaculture or aquaculture. The Department of Fisheries and Aquaculture FAO (Food and Agriculture Organization) puts patin fish in fourth place after goldfish (Cyprinus carpio). Patin fish is also a commodity with high economic value because it has a high selling price and is continuously needed by the community. Patin fish farming has a lower risk than other freshwater fish farming. In addition, patin fish cultivation also does not require high technology, so that everyone can cultivate it.

According to Wild World Found (2015), to support the success of fish farming activities, cultivators must understand it. Things that need to be understood are the selection of cultivation locations, preparation of cultivation facilities and infrastructure, preparation and distribution of seeds, preparation and feeding, maintenance, control of pests and diseases, harvest and postharvest.

Technical aspects of patin fish enlargement business include business location, infrastructure and means of cultivation, production factors for patin fish enlargement business, patin fish cultivation activities starting from pond preparation, seed preparation, feed, patin fish maintenance to patin fish harvesting process and the results obtained. by patin fish enlargement business (Wahidah, 2017). The development of aquaculture business can be carried out optimally if the potential for aquaculture in an area can be well known (Worang, B.C.G.S et al., 2018). Until now, patin fish culture enlargement using pond technology is still experiencing several obstacles and problems internally and externally, but this business faces enormous opportunities because market demand continues to increase so that it can increase people's income (Sushanty et al. 2015).

Based on the description above, this study aims to analyze production management and analyze the financial feasibility of catfish cultivators in Banjar Regency as one of the production centers for catfish cultivation in South Kalimantan Province, whether the business has been well managed and the results can be obtained. Welfare of its cultivators. 


\section{Production Management and Feasibility of Patin (Pangasius Sp.) Cultivation in Banjar Regency, South Kalimantan Province, Indonesia}

\section{RESEARCH METHODOLOGY}

\section{Research Locations and Respondents}

The research location was determined purposively in Banjar Regency, the respondents were patin fish cultivators in the pond which were taken purposively, totaling 50 respondents.

\section{Data Collection Techniques and Types of Data}

This study used a survey method, limited to information collected from a sample representing the entire population using a questionnaire as an instrument in data collection, while the sample selection was carried out by purposive random sampling. The collection technique uses interview techniques related to production management, production infrastructure, and input, output and production prices. The types of data collected consist of primary and secondary data.

\section{Data Analysis Method}

Data analysis aims to simplify data in a form that is easier to understand (Nazir \& Muhammad, 1988). Particularly for qualitative data, the information collected in this study is grouped, then compiled and analyzed in a descriptive qualitative manner. The analysis of the first objective is carried out by collecting data on the production system and various inputs and sources as well as the technical production of patin fish culture which is then described. To determine the feasibility of patin fish farming, the Return Cost of Ratio (RCR), Payback Period (PP) and Break Even Point (BEP) are used.

RCR analysis is a comparison (ratio) between revenue and costs (Kasmir \& Jakfar, 2009), it can be stated in the following formula:

$$
\mathrm{RCR}=\mathrm{TR} / \mathrm{TC}
$$

Remarks:

$$
\begin{array}{ll}
\text { RCR } & =\text { Return Cost of Ratio } \\
\mathrm{TR} & =\text { Total Revenue TR }=\mathrm{Y} \times \mathrm{Py} \\
\mathrm{TC} & =\text { Total Cos } \mathrm{TC}=\mathrm{FC}+\mathrm{VC}
\end{array}
$$

Decision criteria:

$R C R>1$, farming profits

$\mathrm{RCR}<1$, farming loss

$R C R=1$, break even farming

The payback period method is a technique of assessing the period of return on an investment in a business (Kasmir \& Jakfar, 2009), calculated by the formula:

$$
\text { Payback Period }(P P)=\frac{\text { Total Investment }}{\text { Total Profit }} \times 1 \text { year }
$$

Break Even Point Analysis (BEP) is an analysis technique that is shown to produce information and by focusing on determining a situation where the volume of activity (as measured by sales) does not generate profits but also does not experience losses (Sunyoto, 2013) with two approaches, namely:

$$
\begin{gathered}
\text { BEP production }=\frac{\text { Total operational cost }}{\text { Output Selling Price }} \\
\text { BEP price }=\frac{\text { Total operational cost }}{\text { total production }}
\end{gathered}
$$

\section{RESULT AND DISCUSSION}

The patin fish culture in Banjar Regency is a pond system, namely cultivation using a soil pool, a cement pond and a tarpaulin pond. The locations for pond cultivation are scattered in various districts by utilizing a technical irrigation system (drainage) covering an area of 25,900 ha. It stretches for $40 \mathrm{~km}$ from Mandikapau village, Karang Intan District to Sungai Tabuk District. The potential of this irrigation water has been exploited by the community on an area of 413 ha for pond cultivation with various fish commodities, especially patin fish. One of the things that is very important in the initial planning of patin fish farming is the location selection, because choosing the right location will determine the success of this business. In general, a good location for patin fish farming activities is in ponds, rivers, reservoirs, lakes, and other puddles that meet technical requirements (Irwan et al., 2015). The location selection for patin fish cultivation in Banjar Regency is appropriate because it is near to water sources and good water quality because irrigation water flow has not been polluted and does not come from agricultural waste.

\section{Production Management}

Production management activities carried out by patin fish cultivators in Banjar Regency include pre-production, production and post-production activities 


\section{Production Management and Feasibility of Patin (Pangasius Sp.) Cultivation in Banjar Regency, South Kalimantan Province, Indonesia}

\section{a) Pre Production}

Pre-production is the entire preparation stage that is carried out before the production process is carried out. Pre-production activities in patin fish rearing starts from pond preparation such as pond cleaning and drying, liming, filling water and administering water medicine, ordering fish seeds and installing hapa / nets for seedlings (Capture 1)

The first stage of the patin fish enlargement process is cleaning the pond and drying / reducing pond water. The pond used by the cultivators uses muddy soil with varying pond sizes ranging from the smallest $22 \times 10 \mathrm{~m} 2$ size and the largest $30 \times 15 \mathrm{~m} 2$ pond size with a water level of $1.5 \mathrm{~m}$. cleaning and drying of pond water is carried out after harvesting the fish.

Drying the pond using a water pump machine and suctioning water with a hose / water pipe. The drainage channel can also be used for watering the rice fields around the pond. Drying aims to kill bacteria, remove chemical toxic residues that settle at the bottom of the pond from fish food residue and eradicate pests. After low tide, cleaning the pond is carried out such as cutting the weeds that grow around the pond, removing water hyacinths, moss and leaves that are scattered in the pool so that they avoid various diseases in fish seeds.

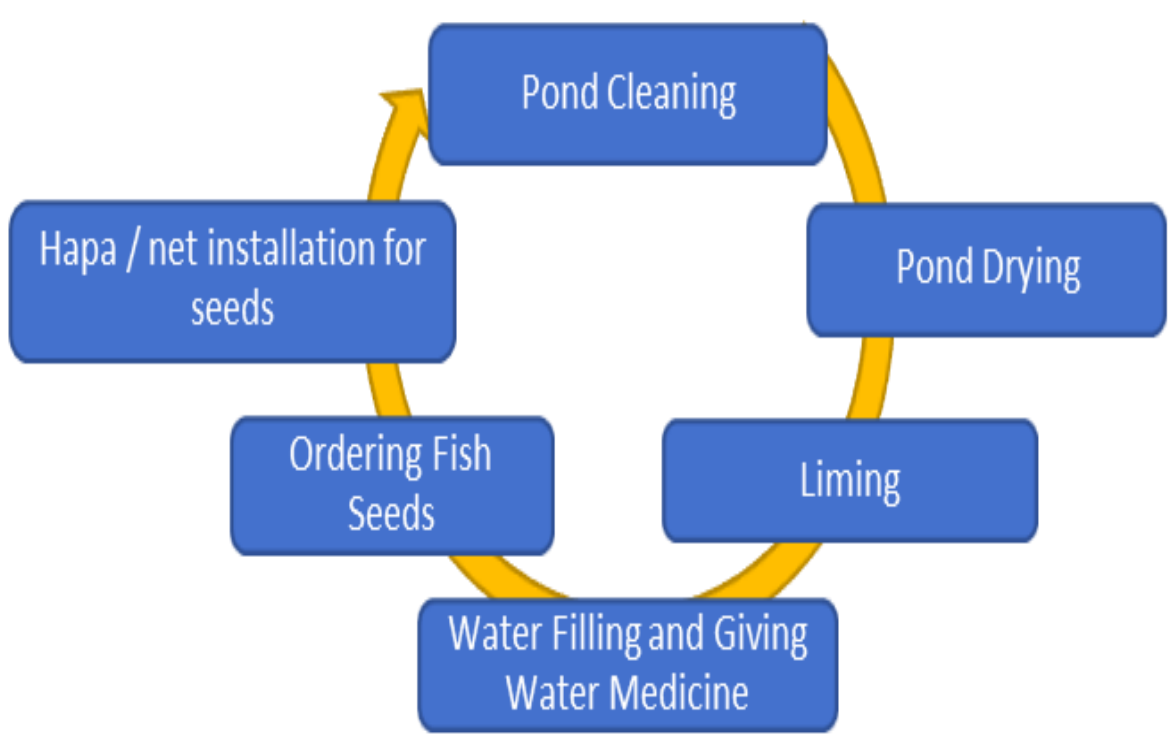

Capture 1. Pre-Production Diagram

The second stage is liming with the aim of increasing soil and water $\mathrm{pH}$, improving the quality of pond soil and eradicating microorganisms that cause aquatic animals. Liming is carried out after the pond has been dried for $2-3$ days. The liming process uses lime by spreading lime as much as $50 \mathrm{~kg}$ evenly to the bottom of the pond soil and then the bottom soil of the pond is reversed with a hoe so that the lime can further enter the bottom soil layer of the pond.

The third stage is filling the water and giving water medicine. The main source of water used to irrigate ponds comes from irrigation water. Water filling is carried out by means of a water irrigation system to irrigate and make it easier for water to enter the fish pond. Collecting water using a pipe with a size of 5 inches from the irrigation source. After filling the water, a water medicine is administered which aims to purify the pond water and improve the water quality so that the fish do not experience stress.

The fourth stage is ordering fish seeds. Cultivators usually buy fish seeds from local hatcheries (Cindai Alus, BPBAT Mandiangin, and the nearest hatchery) and most of them come from Bogor. The seeds that come from around the cultivators are carried by the fish seed sellers themselves using private vehicles, the seeds are wrapped in plastic and put in oxygen into the plastic so that the fish seeds can still live on the way to the fish rearing place. The seeds purchased usually have a size of $3-7$ inches $(1-2.5$ months old) with a weight of \pm 50 gram / fish.

After ordering the seeds, the next step is the installation of hapa / nets. The purpose of installing hapa / nets is for temporary storage of seedlings before planting into the pond so that the seeds do not experience stress due to changes in water and the place of development. The hapa or nets used are usually made of small woven mesh with a size of $1 \times 1$ with a depth of $0.5 \mathrm{~m}$, immersed in water with the open side facing upwards, tied with bamboo sticks stuck to the bottom of the pond, hapa must float and the bottom of the hapa not can touch the bottom of the pool. 


\section{Production Management and Feasibility of Patin (Pangasius Sp.) Cultivation in Banjar Regency, South Kalimantan Province, Indonesia}

\section{b) Production}

Production is the process of enlarging fish from seed to fish ready for consumption. The production stage starts from sowing seeds, offering feed, managing water quality, increasing fish populations and handling pests and diseases.

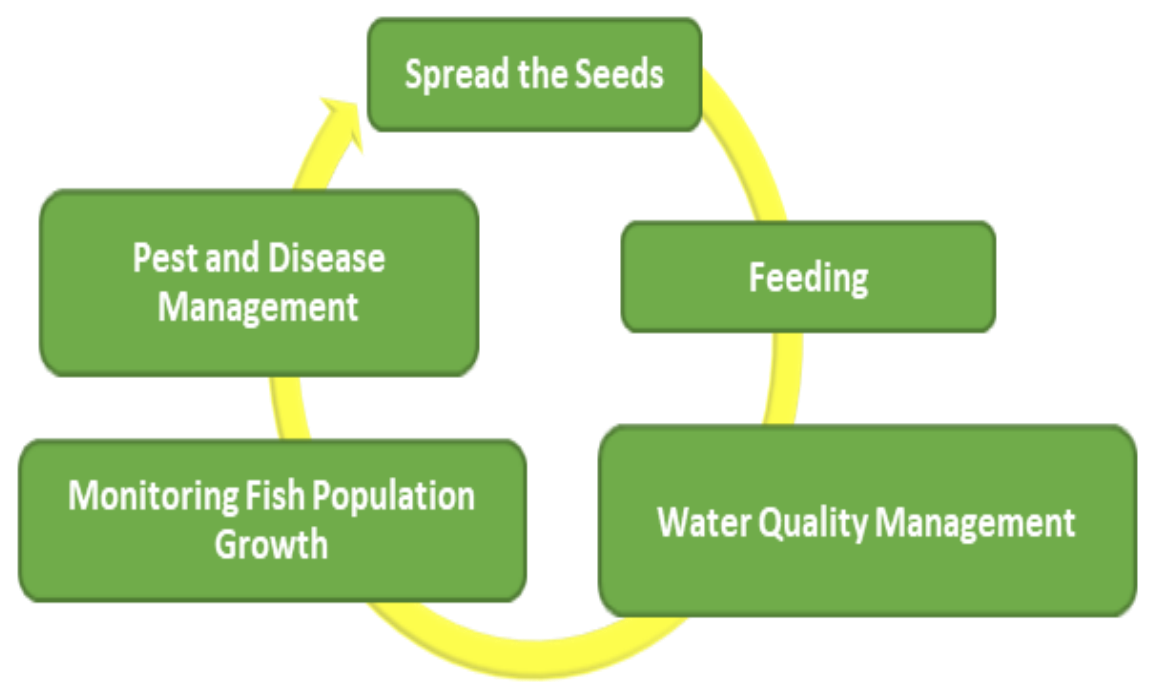

Capture 2. Production Diagram

The first stage of sowing seeds is carried out after the preparation of the container or maintenance pond is ready for use. The average stocking density of seeds is 4,000 - 10,000 individuals / $\mathrm{m} 2$. Before the seeds are spread into hapa / net cages, the seeds are removed from a plastic bag filled with oxygen, the seeds are left for 15 minutes in a pond that has been prepared for the purpose of adjusting to the new environment and temperature first. After that the seeds are spread slowly into the hapa / net cages that have been prepared in the morning or evening to prevent the seeds from experiencing stress. The seeds are maintained for about 2 months before being transferred to a large pond for growth.

The second stage of feeding can be done after the fourth day the fish are stocked because the freshly stocked fish is fasted first to reduce the amount of uneaten food and the process of adapting to the new environment. In patin fish enlargement, the amount and size of the feed affects the growth of the fish. The types of feed used are submerged feed such as Cargil, $885 \mathrm{CP}$ and Pilar from central from PT. Shinta prima Feedmill. Feed is given 2 times a day, namely in the morning at 07.00 WIB and in the afternoon at 16.00 WIB. Feeding is done by throwing it into the pool using the scoop media that has been available at the edge of the pool.

The third stage is water quality management by directly monitoring changes in water color, odors, and changes in temperature. Water quality management is carried out by administering 1 bottle of water medicine per month with the aim of improving water quality for the survival of the fish.

The fourth stage is monitoring the growth of the fish population, which is carried out once a week by using a litter, the fish is taken and placed in the pond for measurements. Pests can be in the form of monitor lizards, water snakes and other aquatic animals, while diseases that can occur in fish are fungi or parasites caused by environmental conditions. Pest and disease management can be done by controlling the condition of the pond water, giving pond water medicine and vitamins to the fish during feeding. The health condition of fish and the cleanliness of the water must always be controlled so that they can be immediately handled properly and can take both prevention and treatment.

\section{c) Post Production}

Post-production is the process of marketing ready-to-consume fish. Post-production activities are carried out after raising catfish for 6 months. Post production activities, namely harvest, post-harvest and pond cleaning.

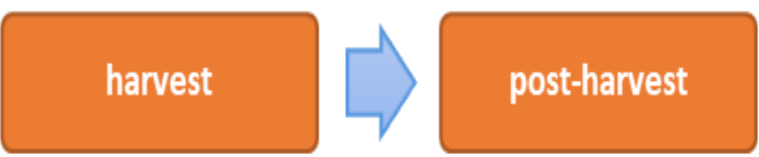

Capture 3. Post-Production Diagram 


\section{Production Management and Feasibility of Patin (Pangasius Sp.) Cultivation in Banjar Regency, South Kalimantan Province, Indonesia}

Harvesting is done if the size of the fish has met the demand for marketing, namely 600-800 gram / fish and the maximum amount of feed that has been given during maintenance, the fish can be harvested and sold, but changes in weather also affect water quality if the $\mathrm{pH}$ of the water decreases and there are some fish experiencing the death of the fish, the fish is ready to be harvested in order to avoid losses. Before harvesting the fish, fasting it first to reduce or eliminate the smell of mud in the catfish meat.

The harvest technique used is to drain the pool water using a water pump machine to simplify the harvest process. Harvesting activities are carried out by the collector traders subordinates and the harvesting wage costs are borne by the collecting traders so that the cultivators do not pay for harvest wages. Then the harvesting process uses a net that is stretched to the right and left then pulled one direction forward until the end of the pond and the bottom of the net is attached to the pond wall and then pulled up. The patin fish is taken by hand and sorted before being put into sacks. Sorting is needed to separate the fish by size, so that it will be easier during the packing process. The weighing of fish using sack media and packaging is put into a barrel that is already filled with water if the shipping distance is long or Styrofoam if the delivery distance is close enough to the market or consumer location.

Post-harvest process by handling live fish and fresh fish. The large number of consumer demands for live patin fish makes the price of live fish expensive if it is sold alive. Catching and transporting are done carefully so that the fish are not injured. Harvesting is done in the morning before the sun is high and using a barrel that is already filled with water from the pond so there is no change and the fish do not die. Handling of fresh fish is by using a clean block filled with ice cubes that have been cut into small pieces and coated with ice above and below in order to maintain the freshness of the patin fish. Patin fish is distributed to various markets inside and outside the South Kalimantan region.

After the post-harvest process, cleaning the pond is carried out with one day of pool cleaning for 1 pond. For cleaning this pond, the cultivators use paid labor from outside. Cleaning the pond includes removing weeds, water hyacinth and moss on the surface of the pond.

The requirements for conformity assessment according to Good Fish Cultivation Practices based on the Decree of the Minister of Marine Affairs and Fisheries Number 02 / MEN / 2007 include: location, water supply, layout and design, cleanliness of facilities and equipment, preparation of cultivation containers, water management, seeds, feed, use of chemicals, biological and medicinal materials for fish, use of ice and water, harvesting, handling of produce, transportation, waste disposal, recording, corrective action, training and personnel hygiene have been carried out mostly in the catfish farming business in Banjar Regency.

\section{b. Business Feasibility}

A fishery business to be carried out by an entrepreneur must generate sustainable profits. Therefore, it is necessary to carry out a business analysis to determine the feasibility level of a type of business. The purpose of business analysis is to determine the level of profit, return on investment and the break-even point of a business. Various anticipations to improve and increase company profits can also be carried out if a business analysis is carried out. Business analysis in fisheries is very necessary given the considerable business uncertainty (Yulinda, 2012).

Analysis of the profit and feasibility of patin fish farming in Banjar Regency needs to be done, to determine the sustainability of this cultivation business in the future financially. Based on the data obtained from respondents in this cultivation business, a summary of the results of the business feasibility analysis of patin fish cultivators is shown in Table 2.

Table 2. Feasibility of Patin Cultivation in Banjar Regency, South Kalimantan, 2021

\begin{tabular}{|c|c|c|}
\hline Number & Description & Value \\
\hline 1. & $\begin{array}{ll}\text { Income } & \\
- & \text { production (kg) } \\
- & \text { price (IDR / kg) } \\
- & \text { income (IDR) } \\
\end{array}$ & $\begin{array}{l}37,658.00 \\
16,000.00 \\
602,528,000.00\end{array}$ \\
\hline 2 & $\begin{array}{ll}\text { Cost } & \\
- & \text { investation (IDR) } \\
\text { - } & \text { fixed (IDR) } \\
- & \text { variabel (IDR) } \\
\end{array}$ & $\begin{array}{l}137,805,000.00 \\
4,754,500.00 \\
411,890,000.00\end{array}$ \\
\hline 3 & Profit (IDR) & $185,883,500.00$ \\
\hline 4 & $\begin{array}{ll}\text { Bussines feasibility } \\
\text { - } & \text { R/C Ratio } \\
\text { - } & \text { Payback Period (year) } \\
\text { - } & \text { BEP Price (IDR) } \\
\text { - } & \text { BEP Production }(\mathrm{kg})\end{array}$ & $\begin{array}{l}1.45 \\
0.74 \\
11,063.90 \\
26,040.28\end{array}$ \\
\hline
\end{tabular}




\section{Production Management and Feasibility of Patin (Pangasius Sp.) Cultivation in Banjar Regency, South Kalimantan Province, Indonesia}

Investment costs are the initial costs incurred in the first year of business activity which are useful for meeting the facilities and infrastructure needed to run a business. The investment cost (IDR 137,805,000.00) in patin fish farming in Banjar Regency consists of costs for land and pond processing (91\%), purchasing keramba / hapa (1.4\%), wood / bamboo (0.8\%). ), buckets $(0.3 \%)$, scoops $(0.1 \%)$, water pump machines $(6.3 \%)$, and pipes for the construction of channels $(0.2 \%)$ with the largest investment cost components being land purchase and processing costs ponds (91\%).

Fixed costs are business expenses that do not depend on the level of goods or services produced by the business. Fixed costs (IDR 4,754,500.00) incurred by patin fish cultivators consist of pond maintenance costs (9\%), machine maintenance costs (27\%), cages maintenance costs (34\%) and depreciation of investment goods (32\%) with the highest fixed cost component is the cage maintenance cost.

Variable costs are costs incurred when production activities take place and may change in line or follow the amount of production produced in cultivation activities. Variable costs (IDR 411,890,000.00) incurred by patin fish cultivators consist of costs for purchasing fish seeds $(8.8 \%)$, fish feed $(87.1 \%)$, medicine $(0.8 \%)$, vitamins $(0,2 \%)$, lime $(0.5 \%)$, gasoline $(1.7 \%)$ and wages for labor $(0.9 \%)$ with the largest cost component being the cost of purchasing feed.

The average production amount in patin fish farming in Banjar Regency in one year or in two production times is $37,658 \mathrm{~kg}$ with an average selling price of IDR 16,000.00/ kg, patin fish enlargement is carried out in an actuary range of 6 - 7 months depending from the condition of the seeds and the price prevailing in the market. The average revenue from patin fish farming in the Banjar district is IDR 553,257,000.00 per year.

Profits are the result of reducing revenues by the total cost of production. The average profit obtained by patin fish cultivators in the Banjar district is IDR $185,883,500.00$ per year.

From the various costs incurred and the revenues obtained, the Revenue Cost Ratio (R / C) value is 1.37. The patin fish farming business in Banjar Regency is declared feasible because the R / C value is greater than 1 (Kasmir \& Jakfar, 2009), which is 1.37. The $R$ / C value of 1.45 means that for every production cost incurred of IDR 1,000,000.00 an income of IDR 1,450,000.00 will be obtained. Payback Period (PP) or the period of return on investment in this business is 0.74 years. The rate of return on capital of a business is categorized as fast if the PP value is $<3$ years, the rate of return on capital is categorized as moderate if the PP value is 3 years $<$ PP $<5$ years, and it is said to be in the slow rate of return category if the PP value is $>5$ years (Riyanto, 2001). This means that the catfish farming business in Banjar Regency is very feasible to run because the investment return period is relatively fast, far below 3 years. Based on the results of the analysis in Table 2, the BEP value of production is $26,040,28 \mathrm{~kg}$, indicating that the break-even point or business conditions of no profit or no loss will be achieved at the time of business production of $26,040,28 \mathrm{~kg}$. Meanwhile, the BEP value is IDR 11,063.90 indicates that the break-even point or the condition of the company being not profitable or not losing will be achieved when the selling price of catfish is IDR 11,063.90 per kg. Based on the analysis of production BEP and price BEP, catfish farming in Banjar Regency, South Kalimantan is profitable and feasible to develop because the BEP production value obtained is below the annual production level of $37,658 \mathrm{~kg}$ and the BEP value is below the current selling price of IDR 16,000. 00 (Sunyoto, 2013).

\section{CONCLUSIONS}

Production management that is carried out in the patin fish farming business in Banjar Regency consists of pre-production management, production and post-production management and most of the Good Fish Cultivation Practices according to the Decree of the Minister of Marine Affairs and Fisheries RI Number 02 / MEN / 2007 have been carried out in management. Production of this venture. The patin fish farming business in Banjar Regency is financially profitable and feasible to develop.

\section{REFERENCES}

1) Andriyanto, S., Tahapari, E dan Insan, I. 2012. Pendederan Ikan Patin di Kolam Oudoor untuk Menghasilkan Benih Siap Tebar Di Waduk Malahayu, Breebes, Jawa Tengah. Media Akuakultur Volume 7 Nomor 1 Tahun 2012. http://ejournalbalitbang.kkp.go.id/index.php/ma/article/view/976

2) Badan Pusat Statistik, 2020. Kabupaten Banjar dalam Angka. Badan Pusat Statistik Kabupaten Banjar Provinsi Kalimantan Selatan.

3) Dinas Perikanan Kabupaten Banjar, 2016. Rencana Strategis 2016 - 2021

4) Efendi, I. 2004. Pengantar Akuakultur. (Jakarta : PS)

5) Irwan, Marhadi, Komara, Alpian, N., Pamungkas, A.J., Firdausi, 2015. Budidaya Ikan Patin Siam ( Pangasius hypophthalmus ) Sistem Kolam, Karamba Jaring Tancap, Dan Karamba Jaring Apung. Seri Panduan Perikanan Skala Kecil Edisi 1. Tim Perikanan WWF-Indonesia.) 
Production Management and Feasibility of Patin (Pangasius Sp.) Cultivation in Banjar Regency, South Kalimantan Province, Indonesia

6) Kasmir \& Jakfar. (2009). Studi Kelayakan Bisnis. Kencana Prenada Media Group. Jakarta.

7) $[$ KKP] Kementerian Kelautan dan Perikanan. 2016. Laporan Kinerja (LKJ) Direktorat Jendral Perikanan Budidaya tahun 2016. Jakarta (ID) : KKP

8) Keputusan Menteri Kelautan dan Perikanan No. 2/MEN/2007. CBIB (Cara-cara Budidaya Ikan yang Baik).

9) Nazir \& Muhammad. (1988). Metode Penelitian. Jakarta. ID: Ghalia Indonesia

10) Puspita dan Ahmad, W., 2014. Budidaya Patin Cepat Panen.Penerbit Infra Pustaka, Jakarta,.

11) Rejeki, S., Aryati, R.W., Widowati, L.L., 2019. Pengantar Akuakultur. UNDIP Press. Semarang

12) Riyanto. (2001). Dasar-Dasar Pembelajaran Perusahaan. Yayasan Badan Penerbit Universitas Gajah Mada. Yogyakarta.

13) Sunyoto, (2013). Analisis Laporan Keuangan Untuk Bisnis (Teori dan kasus). Jl. Cempaka Putih No.8 Deresan CT X, Gejayan , Yogyakarta.

14) Suraya, U. 2016. Penerapan Teknologi Budidaya Ikan Lele Sangkuriang Di Kolam Tanah Pada Kegiatan Bina Desa Upt 38 Keluraan Sei Gohong : Jurnal Udayana Mengabdi. Volume $15 \quad$ Nomor 2. https://ojs.unud.ac.id/index.php/jum/article/view/22556

15) Sushanty, DE., Fauziah dan Priadi, DP. 2017. Strategi Pengembangan Usaha Budidaya Pembesaran Ikan Patin (Pangasius Sp.) Di Kecamatan Gandus Kota Palembang : Jurnal Teknologi Hasil Perikanan. Volume 6 Nomor 2. https://ejournal.unsri.ac.id/index.php/fishtech/article/view/5844/3180

16) Wahidah, A.N., 2017. Analisis Kelayakan Usaha Pembesaran Ikan Patin Pada Usaha Perseorangan "Tirto Mas Farm” Di Kelurahan Beduri Kabupaten Ponorogo Provinsi Jawa Timur. Sarjana thesis, Universitas Brawijaya. Malang

17) Wild World Found Indonesia, 2015. Better Management Practise (BMP) Ikan Patin Siam Sistem Kolam, Keramba Jaring Tancap dan Keramba Jaring Apung. WWF-Indonesia: Jakarta.

18) Worang, B.C.G.S., Sinjal. dan Monijung, RD. 2018. Strategi Pengembangan Budidaya Perikanan Air Tawar di Kecamatan Dimembe Kabupaten Minahasa Utara Provinsi Sulawesi Utara. Jurnal Budidaya Perairan. Volume 6 Nomor 2 tahun 2018. Halaman 68-76. Universitas Sam Ratulangi.

https://ejournal.unsrat.ac.id/index.php/bdp/article/view/20635/20251

19) Youdastyo, 2010. Wisata Perikanan. Komplek Wisata perikanan Kalittirto, II 3-37.

20) Yulinda, E. (2012). Analisi Finansial Usaha Pembenihan Ikan Lele Dumbo (Clarias gariepinus) Di Kelurahan Lembah Sari Kecamatan Rumbai Pesisir Kota Pekanbaru Provinsi Riau. Jurnal Perikanan dan Kelautan 17,1(2012):38-55. https://ipk.ejournal.unri.ac.id/index.php/JPK/article/view/62 